\title{
Contribution of methane to aerosol carbon mass
}

\author{
F. Bianchi ${ }^{1,2}$, P. Barmet ${ }^{1}$, L. Stirnweis ${ }^{1}$, I. El Haddad ${ }^{1}$, S.M. Platt ${ }^{1,+}$, M. \\ Saurer $^{1}$, C. Lötscher ${ }^{1}$, R. Siegwolf ${ }^{1}$, A. Bigi ${ }^{3}$, C.R. Hoyle ${ }^{1,4}$, P.F. \\ DeCarlo ${ }^{1, *}$, J.G. Slowik ${ }^{1}$, A.S.H. Prévôt' ${ }^{1}$, U. Baltensperger ${ }^{1}$, and J. \\ Dommen ${ }^{1}$
}

${ }^{1}$ Laboratory of Atmospheric Chemistry, Paul Scherrer Institute, Villigen,

Switzerland

${ }^{2}$ Department of Physics, University of Helsinki, Helsinki, Finland

${ }^{3}$ Department of Engineering "Enzo Ferrari", University of Modena and Reggio Emilia, Modena, Italy

${ }^{4}$ WSL Institute for Snow and Avalanche Research SLF, CH-7260 Davos, Switzerland

* now at: Department of Civil Architectural and Environmental Engineering, Drexel and Department of Chemistry University, Philadelphia, PA, USA

${ }^{+}$now at: Department of Atmosphere and Climate, Norwegian Institute for Air Research (NILU), 2007 Kjeller, Norway

Correspondence to: josef.dommen@psi.ch

\section{Abstract}

Small volatile organic compounds (VOC) such as methane $\left(\mathrm{CH}_{4}\right)$ have long been considered non-relevant to aerosol formation due to the high volatility of their oxidation products. However, even low aerosol yields from $\mathrm{CH}_{4}$, the most abundant VOC in the atmosphere, would contribute significantly to the total particulate carbon budget. In this study, organic aerosol (OA) mass yields from $\mathrm{CH}_{4}$ oxidation were evaluated at the Paul Scherrer Institute (PSI) smog chamber in the presence of inorganic and organic seed aerosols. Using labeled ${ }^{13} \mathrm{C}$ methane, we could detect its oxidation products in the aerosol phase, with yields up to $0.09\left({ }_{-\mathbf{0 . 1 0}}^{+\mathbf{0 . 2 6}}\right) \%$. Overall, we estimate a maximum contribution of $\mathrm{CH}_{4}$ oxidation of $0.13 \%$ to the total global organic aerosol budget. We present evidence that oxidation of formaldehyde, a product of methane oxidation, contributes only a minor fraction to the observed 
aerosol yields. Therefore, other mechanisms appear to be more important for OA production from $\mathrm{CH}_{4}$ oxidation. A thorough elucidation of such mechanisms is still required. However, our results imply that many other small, volatile, and abundant hydrocarbons thus far considered irrelevant for OA production may contribute to the atmospheric OA budget.

Keywords: methane, VOC, OH oxidation, secondary organic aerosol, aerosol yield, stable isotope

\section{Introduction}

Atmospheric organic aerosols (OA) can be emitted directly into the atmopshere (primary organic aerosol, POA) or formed in the atmosphere via the oxidation of gaseous precursors and the subsequent condensation of the resulting semi-volatile and low volatility products (secondary organic aerosol, SOA). Based on a comparison between bottom-up model estimates and various top-down approaches, Hallquist et al. (2009) concluded that the global SOA budget is poorly constrained. The oxidation products of small carbonyls and hydrocarbons have long been considered irrelevant to secondary aerosol formation due to their high volatility. However this view must be re-evaluated as a result of the discovery that isoprene reaction products, despite being relatively small molecules, have sufficiently low volatility to condense on particles. Condensed-phase reactions can increase the molecular weight and strongly reduce the volatility distribution of organic species. VOCs as small as acetylene $\left(\mathrm{C}_{2} \mathrm{H}_{2}\right)$ have also been mooted as SOA precursors (Volkamer et al., 2009). 
Methane $\left(\mathrm{CH}_{4}\right)$, the most abundant VOC in the atmosphere, is the focus of much research due to its strong radiative forcing and its reactivity. In addition, it is still unknown if the oxidation of $\mathrm{CH}_{4}$ contributes to SOA formation. Such a contribution would be important because (1) the atmospheric $\mathrm{CH}_{4}$ concentration $(\sim 1800 \mathrm{ppbv}$, Dlugokencky et al., 2009) has roughly doubled since the preindustrial era ( $~ 800$ ppbv, Spahni et al., 2005); (2) if $\mathrm{CH}_{4}$ were to contribute to SOA formation, this would mean it is becoming increasing important; (3) a finding that $\mathrm{CH}_{4}$ contributes to SOA formation would suggest that many other previously unconsidered small VOCs may also do so.

Here, we present the results of experiments carried out at the Paul Scherrer Institute (PSI) smog chamber to assess the SOA formation potential of $\mathrm{CH}_{4}$ oxidation products. To the best of our knowledge, this study represents the first investigation of SOA formation from $\mathrm{CH}_{4}$.

\section{Methodology}

Isotopically labeled methane $\left({ }^{13} \mathrm{CH}_{4}\right)$ or formaldehde $\left(\mathrm{H}^{13} \mathrm{CHO}\right)$ was used to enable their condensed oxidation products to be distinguished from the organic seed aerosol that was injected into the chamber. The particles were monitored online by an Aerodyne high-resolution time-of-flight aerosol mass spectrometer (HR-ToF-AMS) and the ${ }^{13} \mathrm{C} /{ }^{12} \mathrm{C}$ ratio was measured by off-line isotope ratio mass spectrometry (IR-MS). Other instruments were operated to measure the particle number size distribution and to quantify trace gas concentrations, as described below. 


\subsection{Instruments}

Aerosol particle number size distribution (for particles with diameters between 20 and $800 \mathrm{~nm}$ ) and chemical composition were measured with a scanning mobility particle sizer (SMPS) and an HR-ToF-AMS, respectively. The HR-ToF-AMS provides quantitative size-resolved mass spectra of the non-refractory aerosol, including ammonium nitrate and sulfate and organic aerosol, using a combination of flash vaporization and electron impact ionization. VOCs with a proton affinity higher than water were measured by a high sensitivity proton transfer reaction mass spectrometer (PTR-MS, IONICON). The PTR-MS is equipped with a quadrupole mass spectrometer at unit mass resolution and is able to detect VOCs at the low ppt level (Lindinger et al., 1998). Further gas phase instruments included $\mathrm{NO}_{\mathrm{x}}$ monitors (Monitor Labs 9841A, Thermo Environmental Instruments 42C with photolysis converter), ozone monitors (Monitor Labs 8810, Environics S300), a CO monitor (AERO-LASER GmbH AL5002) as well as an instrument for formaldehyde measurement by means of the Hantzsch reaction (Junkermann and Burger, 2006). The total hydrocarbon concentration was determined using a flame ionization detector (FID) (experiemntal series 1: J.U.M. Engineering GmbH J.U.M FID V E7, experimental series 2 and 3: Horiba Ambient THC Monitor APHA-370). During series 2 and 3 we also used a PICARRO (Picarro Cavity Ring-Down Spectrometer G2401) to quantify $\mathrm{CO}_{2}, \mathrm{CO}, \mathrm{CH}_{4}$ and $\mathrm{H}_{2} \mathrm{O}$. This instrument measures only ${ }^{12} \mathrm{CO}$ while the AL5002 measures total $\mathrm{CO}\left({ }^{12} \mathrm{CO}+{ }^{13} \mathrm{CO}\right)$. Aerosol samples were collected on tinfoil in an impactor (built according to Williams et al. (2006)) as well as on quartz filters, which then were burnt in an oxygen rich environment in an 
elemental analyzer (EA-1110, Carlo Erba Thermoquest, Milan, Italy) coupled (in continuous flow mode) to the inlet of the IR-MS (Delta S for series 1 and MAT 253 for series 2 and 3, both Thermo Science Finnigan) as described in Dommen et al. (2009). In addition, the amount of ${ }^{13} \mathrm{C}$ in $\mathrm{CO}$ and $\mathrm{CO}_{2}$ from gas samples was determined by IR-MS.

\subsection{Smog chamber experiments}

Four series of experiments (Table 1) were performed at the PSI smog chamber (Paulsen et al., 2005). The chamber is a $27 \mathrm{~m}^{3}$ Teflon bag in a temperature controlled housing, with four filtered xenon lamps providing quasi-solar illumination. Additional UV lights were also used (black lights emitting mainly between 320 and $400 \mathrm{~nm}$; Philips, Cleo performance solarium lamps; in total 80 tubes with $100 \mathrm{~W}$ per tube). Before each experimental series, the smog chamber was cleaned by the injection of several ppmv of ozone and irradiating for $10 \mathrm{~h}$ with UV lights at $20^{\circ} \mathrm{C}$, followed by flushing with pure air at high relative humidity (above $60 \%$ ) at $30^{\circ} \mathrm{C}$ for at least 20h. Each experimental series lasted between two and four days. At the beginning of each experiment, the clean smog chamber was humidified to a relative humidity (RH) slightly above $85 \%$, at a temperature of $21 \pm 1{ }^{\circ} \mathrm{C}$. These conditions remained stable during the course of experiments.

\section{Series 1 and 2}

The first two experimental series started by injecting an inorganic seed aerosol (ammonium sulfate for series 1 and ammonium bisulfate for series 2) to a concentration of $15-20 \mu \mathrm{g} / \mathrm{m}^{3}$. Thereafter, $500 \mathrm{ppbv}$ of $\mathrm{O}_{3}$ was added followed by a 
slow injection of $80 \mathrm{ppbv}$ of $\alpha$-pinene. Upon the consumption of all $\alpha$-pinene by ozonolysis, approximately $75 \mathrm{ppmv}$ of ${ }^{13} \mathrm{CH}_{4} \quad 0.99$ atom fraction ${ }^{13} \mathrm{C}$, Sigma-Aldrich) was added, and photochemical oxidation by $\mathrm{OH}$ with the smog chamber lights switched on followed. On the subsequent days the chamber was refilled with clean, humid air to compensate for chamber volume lost during sampling. The inorganic and organic SOA was almost completely lost to the walls and was renewed daily by nebulizing the inorganic seed and by injecting $80 \mathrm{ppbv}$ of fresh $\alpha$-pinene. ${ }^{13} \mathrm{CH}_{4}$ was also added every day (up to $75 \mathrm{ppmv}$ ) to compensate for the volume loss. Refilling was done into the non-illuminated chamber and lights were swithed on again after methane injection. While long experiments have limitations regarding the particles that are lost to the walls, the gas phase oxidation products can still accumulate, meaning that conditions in the chamber are representative of longer $\mathrm{CH}_{4}$ reaction times.

In series 1, NO was injected continuously from a gas cylinder (Messer, 1005 ppmv NO in $\mathrm{N}_{2}(99.999 \%)$ ) at a flow of $10 \mathrm{ml} \mathrm{min}^{-1}$ from the time when the lights were switched on until the last sample of the day was taken (about 5 hours after lights were switched on). $\mathrm{NO}$ and $\mathrm{NO}_{2}$ concentrations were all the time below 300 ppt and $6 \mathrm{ppb}$, respectively. The continuous NO injection on the two subsequent days started after refilling the chamber. On the third day of series 1, nitrous acid (HONO) was used instead of NO to produce higher $\mathrm{OH}$ concentrations. HONO mixing ratios of $15-20 \mathrm{ppbv}$ in the chamber were reached by passing pure air $\left(21 \mathrm{~min}^{-1}\right)$ through a custom built vessel where sulfuric acid $\left(0.01 \mathrm{M} \mathrm{H}_{2} \mathrm{SO}_{4}\right)$ and sodium nitrite $\left(3 \cdot 10^{-3}\right.$ 
$\mathrm{M} \mathrm{NaNO}_{2}$ ) were reacted. The HONO system is described by Taira and Kanda (1990).

Series 2 was designed to be a 'no- $\mathrm{NO}_{\mathrm{x}}$ ' experiment. In contrast to the 'intermediate $\mathrm{NO}_{x}$ experiment' from series 1, we aimed to increase the amount of (methyl-)peroxides. $\mathrm{OH}$ was generated via the photolysis of $\mathrm{O}_{3}$. Furthermore, we switched the inorganic seed from ammonium sulfate to the slightly acidic ammonium bisulfate, to investigate if the growth of the aerosol is enhanced by acidic seed, as suggested by several authors (Jang et al. 2002; Czoschke et al. 2003; Gao et al. 2004a; Gao et al. 2004b; Iinuma et al. 2004). Similarly to series 1, we had to renew the suspended particle phase every 24 hours - due to wall losses - and add methane as well as clean, humid air to compensate for the volume losses. In contrast to the first series we added $\mathrm{O}_{3}$ daily to maintain a mixing ratio above $500 \mathrm{ppbv}$.

\section{Series 3}

Also in this series, ammonium bisulfate was used as an inorganic seed aerosol but instead of $\alpha$-pinene we added 1,3,5- trimethylbenzene (TMB) as the precursor for the OA seed. In contrast to the two earlier series, ${ }^{13} \mathrm{CH}_{4}$ was injected before the SOA precursor. This was possible because TMB does not react with ozone. After the lights had been on for 3 hours, 500 ppbv TMB (1,3,5-TMB, $98 \%$, Sigma-Aldrich) was injected. SOA production was low due to the low ozone photolysis rate. Approximately 8.5 hours after the lights were switched on and the first samples had been taken (under 'no- $\mathrm{NO}_{\mathrm{x}}$ ' condition), $\mathrm{HONO}$ was added into the chamber (similar to the third day of series 1). Thus additional $\mathrm{OH}$ was generated through the photolysis of HONO (see Figure 1). 


\section{Series 4}

A further goal of these experiments was to uncover whether the uptake of formaldehyde or peroxides is the main reason for the ${ }^{13} \mathrm{C}$ enhancement in the aerosol. Therefore we added ${ }^{13} \mathrm{C}$ labeled formaldehyde $\left(\mathrm{H}^{13} \mathrm{CHO}\right.$ with 0.99 atom fraction ${ }^{13} \mathrm{C}$ ) to two experiments where $\alpha$-pinene was used as the SOA precursor. In the first experiment, $\mathrm{H}^{13} \mathrm{CHO}$ concentrations were simlar to those expected during the methane oxidation ( $\sim 40 \mathrm{ppbv}$ of $\mathrm{H}^{13} \mathrm{CHO}$ ). In the second experiment, very high concentrations were used (> $800 \mathrm{ppbv}$ of $\mathrm{H}^{13} \mathrm{CHO}$ ), which even exceeded the total amount of methane reacted during the methane oxidation experiments.

\subsection{Wall loss correction (wlc) and carbon mass}

\section{determination}

The measured aerosol mass concentration in the smog chamber is the net result of mass produced in the chamber minus mass lost to the walls (Hildebrandt et al., 2011), therefore to calculate the correct yield, a correction must be applied to the measured mass. For the wall loss correction (wlc) we assumed the wall deposition rate constant $\left(k_{w}(t)\right)$ of organic aerosol to be constant over the course of an experiment. $k_{w}$ can be estimated by fitting the observed decay in aerosol mass due to wall loss. This was done by performing a linear fit to the natural logarithm of the measured organic mass, at times in the experiment when no (or hardly any) additional OA was produced (see Figure 1).

The loss of organic vapors onto the clean Teflon walls has been identified as a major source of systematic underestimation of SOA yields from chamber experiments 
(Matsunaga et al., 2010; Zhang et al., 2014). However, as we use relatively high concentrations $\left(>100 \mu \mathrm{g} \mathrm{m}^{-3}\right.$ ), these losses are minor in our case as the effective particle surface area was roughly equivalent to that of the walls (Zhang et al., 2014). Therefore, we did not apply any correction to account for vapour losses to the walls and the yields presented here should be considered as lower estimates.

As the wall loss correction procedure is based on several assumptions and uncertainties, we attempt to bound the uncertainties by varying the determined wall loss rate constant $\left(k_{w}(t)\right)$ by $\pm 50 \%$. This leads to a spread of wall loss corrected organic carbon that is indicated with the semi-transparent green color in Figure 1 and 2. These upper and lower limits of wall loss corrected organic carbon mass were used to determine the uncertainties in the methane yield calculation.

\section{$2.4 \mathrm{OH}$ tracer}

$\mathrm{OH}$ concentrations inside the smog chamber were calculated based on PTR-MS measurement of the decay of tracer compounds with known reaction rates with $\mathrm{OH}$. In the first experimental series pinonaldehyde, an ozonolysis product of $\alpha$-pinene, was used as a tracer to infer the $\mathrm{OH}$ concentration inside the chamber. At the end of the $2^{\text {nd }}$ day, 3-pentanol was injected to determine the $\mathrm{OH}$ concentration for the period when pinonaldehyde had reacted away. In series 2 and 3, following the approach of Barmet et al., (2012), we used an extra OH tracer (9-fold deuterated butanol, 98\%, D9, Cambridge Isotope Laboratories), further referred to as butanol-d9. Before the lights were switched on for the first time, approximately 15 ppbv butanol-d9 was injected into the smog chamber. In series 2 the butanol-d9 had to be renewed after two days. For the $\mathrm{OH}$ determination we used a kinetic 
reaction rate constant of $3.4 \cdot 10^{-12} \mathrm{~cm}^{3}$ molecules ${ }^{-1} \mathrm{~s}^{-1}$ (Barmet et al., 2012). All other $\mathrm{OH}$-reaction rate constants (i.e $\mathrm{OH}+\mathrm{CH}_{4} /$ pinonaldehyde/3-pentanol) were taken from the Master Chemical Mechanism (MCM) web page (http://mcm.leeds.ac.uk/MCM/). The kinetic isotope effect (KIE) for the abstraction of an $\mathrm{H}$-atom from ${ }^{13} \mathrm{CH}_{4}$ by $\mathrm{OH}$ radicals is very small (Cantrell et al., 1990).

\subsection{Modeling}

The first two experimental series were modeled with version 3.1 of the Master Chemical Mechanism (MCMv3.1) (Jenkin et al., 1999; Saunders et al., 2003) including the chamber auxiliary mechanism developed by Metzger et al. (2008). This allowed us to compare the determined $\mathrm{OH}$ concentrations for periods where a tracer was available and to use the modeled $\mathrm{OH}$ concentrations for periods where no $\mathrm{OH}$ tracer was available. This was especially important for the first series, where we did not use butanol-d9 and determined the $\mathrm{OH}$ level based on the decay of pinonaldehyde and 3-pentanol. This further allowed us to estimate the $\mathrm{OH}$ concentration during $\alpha$-pinene ozonolysis. Additionally, the modelling provided insight into the fraction of formaldehyde originating from ${ }^{13} \mathrm{CH}_{4}$. The latter was necessary for the two additional experiments with $\mathrm{H}^{13} \mathrm{CHO}$. 


\section{Results and discussion}

\subsection{Initial stages of each experimental series and methane} yields

We shall first focus only on the findings from the first experimental day of each series. All reported methane carbon-yields are derived from this first stage of an experimental series. Figure 2 shows the first day of series 2 with $\alpha$-pinene as the SOA precursor. The green line shows the wall loss corrected organic carbon mass $( \pm$ wlc uncertainty), whereas the gray line indicates the ${ }^{13} \mathrm{CH}_{4}$ reacted, calculated from the determined $\mathrm{OH}$ concentrations. The uncertainty in the methane reacted results from the sum of the uncertainties of the $\mathrm{OH}$ reaction rates with the tracer and methane, respectively.

The IR-MS provided the ${ }^{13} \mathrm{C}$ atom fraction of the sampled particles and the sample holder (quartz filter or tin foil). The excess atom fraction $\chi^{\mathrm{E}}\left({ }^{13} \mathrm{C}\right)$ was then determined from the difference between the ${ }^{13} \mathrm{C}$ atom fraction of the sample and that of the blank, i.e., the clean sample holder (filter or tinfoil)

$$
\left.\chi^{E}\left({ }^{13} \mathrm{C}\right)=\frac{{ }^{13} \mathrm{C}}{{ }^{12} \mathrm{C}+{ }^{13} \mathrm{C}}(\text { sample })-\frac{{ }^{13} \mathrm{C}}{{ }^{12} \mathrm{C}+{ }^{13} \mathrm{C}} \text { (blank }\right)
$$

The $\chi^{\mathrm{E}}\left({ }^{13} \mathrm{C}\right)$ originates from the condensation of ${ }^{13} \mathrm{CH}_{4}$ oxidation products onto the pre-existing SOA. During the course of the $\alpha$-pinene experiments (series 1 
and 2) the excess atom fraction of ${ }^{13} \mathrm{C}$ in the SOA seed increased with photochemical oxidation time and after 5 to 6 hours after turning the lights on the $\chi^{\mathrm{E}}\left({ }^{13} \mathrm{C}\right)$ reached $7.5 \cdot 10^{-5}$ in both $\alpha$-pinene experiments. The methane aerosol yield $\left(\mathrm{Y}_{\mathrm{CH}_{4}}\right)$ equates to the carbon mass of SOA produced $\left(\Delta \mathrm{M}_{\mathrm{SOC}}\right)$ multiplied by the enhanced ${ }^{13} \mathrm{C}$ carbon fraction and divided by the carbon mass of reacted methane $\left(\Delta \mathrm{M}_{\mathrm{CH}_{4}-\text { reacted }}\right)$ :

$$
Y_{\mathrm{CH}_{4}}=\frac{\Delta \mathrm{M}_{\mathrm{SOC}} \cdot f}{\Delta \mathrm{M}_{\mathrm{CH}_{4}-\text { reacted }}}
$$

where $f=\chi^{\mathrm{E}}\left({ }^{13} \mathrm{C}\right) \cdot \quad$ total carbon collected $\cdot($ total carbon collected-blank carbon $^{-1} \cdot 100 \%$ ), which is the carbon percentage of the collected aerosol that comes from the labeled precursor hydrocarbon $\left({ }^{13} \mathrm{CH}_{4}\right)$. Table 2 gives an overview of all the calculated methane yields (where carbon mass was above $2 \mathrm{\mu g} \mathrm{m}^{-3}$ ). The yields for all the experiments are between $0.007 \%$ and $0.09 \%$. The highest yields were reached in the experiments with $\alpha$-pinene ozonolysis $(0.06 \%-0.09 \%)$, whereby neither the type of the inorganic seed nor the NOx-level had any influence on the yield. For series 3 (with 1,3,5-TMB) the yields were generally lower $(0.007 \%-0.021 \%)$. Especially low yields were found in the first stage of the TMB experiment, that is during the 'no- $\mathrm{NO}_{\mathrm{x}}$ ' regime (not reported in Table 2) when the collected carbon mass was below $2 \mu \mathrm{g}$. The addition of HONO, 8.5 hours after lights on, increased the $\mathrm{OH}$ production substantially and led to an enhancement in methane reacted and SOA mass produced from 1,3,5-TMB oxidation (see also Figure 1). However the observed 
carbon yield was about a quarter of that in the presence of $\alpha$-pinene ozonolysis SOA. Part of this can be explained by the lower seed SOA mass concentration. The atmospheric significance of these yields (between $0.007 \%$ and $0.09 \%$ ) is rather small as the following calculation reveals: The yearly $\mathrm{CH}_{4}$ sink due to reaction with $\mathrm{OH}$ is between 400-500 $\mathrm{TgC}^{-1} \mathrm{ear}^{-1}$ (IPCC, 2013), indicating that between 0.028 and $0.105 \mathrm{TgC}$ year ${ }^{-1}$ of the aerosol could be from $\mathrm{CH}_{4}$. The global SOA budget was determined to be between 80 and $225 \mathrm{TgC}_{\text {year }}{ }^{-1}$ (Hallquist et al., 2009), resulting in a maximal $\mathrm{CH}_{4}$ contribution of $0.13 \%$.

\subsection{Subsequent experiments}

Due to the daily dilutions and the need to replenish the suspended particle phase on the following days, an effective steady state was reached (in terms of ${ }^{13} \mathrm{C}$ atom fraction) in the particle $\chi^{\mathrm{E}}\left({ }^{13} \mathrm{C}\right)$. The measured $\chi^{\mathrm{E}}\left({ }^{13} \mathrm{C}\right)$ in the aerosol remained between $1 \cdot 10^{-4}$ and $1.5 \cdot 10^{-4}$. It is remarkable that this $\chi^{E}$ level was reached after the ozonolysis of the added $\alpha$-pinene (with lights off) in presence of $\mathrm{CH}_{4}$ and was not enhanced by further photochemical oxidation. This result seemed to be independent of the inorganic seed used, the NO or HONO addition, or the amount of $\alpha$-pinene injected (40 or $80 \mathrm{ppbv}$ ). Thus, from the second day on, when the $\mathrm{OH}$ dose in the gas phase exceeds approximately $8 \cdot 10^{7} \mathrm{~cm}^{-3} \mathrm{~h}$, it is meaningless to scale the methane yield to the amount of ${ }^{13} \mathrm{CH}_{4}$ reacted, as the (wall loss corrected) yield would always be highest after the ozonolysis and decrease with further ${ }^{13} \mathrm{CH}_{4}$ oxidation, until the particles are lost to the walls. Methane oxidation products are incapable of 
forming particles on their own. Therefore their SOA yield will depend on the amount and composition of the available seed aerosol and thus on the presence of other oxidizable VOCs in the gas phase. If the pseudo-ideal mixing assumption is valid and SOA from methane oxidation products and from $\alpha$-pinene form a single solution (the ideal-mixing case), the SOA yields of methane as well as of $\alpha$-pinene should be a function of the total suspended organic aerosol concentration, consistent with equilibrium partitioning (Hildebrandt et al., 2011). To elucidate the effect of $\alpha$-pinene SOA mass on the determined methane yield, five $\alpha$-pinene ozonolysis were performed in a row: by the step-wise injection of doses of $30 \mathrm{ppbv}$ of $\alpha$-pinene into the chamber which contained mainly gaseous oxidation products of methane and $\alpha$-pinene, while most of the particles had been lost to the walls. The lights were switched off during the course of these ozonolysis experiments. The first samples, collecting the aerosols from the previous day, did not contain enough carbon mass (less than $1 \mu g$ ) to determine a proper isotopic ratio. The same was the case for the tinfoil sample after the first ozonolysis of (30 ppbv) $\alpha$-pinene. Figure 3 shows the $\chi^{\mathrm{E}}\left({ }^{13} \mathrm{C}\right)$ determined from the aerosol samples. The generally decreasing trend can be explained by the fact that more and more unlabeled $\alpha$-pinene was injected into the smog chamber, while the available labeled methane reacted in the gas phase decreased with each ozonolysis. However, despite the decreasing $\chi^{\mathrm{E}}\left({ }^{13} \mathrm{C}\right)$ in the aerosols, the yields increased with every further $\alpha$-pinene injection resulting in 50 to $350 \mu \mathrm{g} \mathrm{m}^{-3}$ organic carbon (Figure 4).

We are aware of the fact that the methane mixing ratio used here $(75 \mathrm{ppmv})$ is about 40 times higher than in the atmosphere. However, as methane is highly inert, its presence does not affect the experiment until the point where it undergoes 
$\mathrm{H}$-abstraction by the $\mathrm{OH}$. Field results, mostly from regions with significant anthropogenic pollution, suggest that SOA formation occurs on a timescale of one day after emission of the precursors, while ageing of the SOA is rapid at first and continues at a slower rate for at least a week (Hallquist et al., 2009). Indirect measurements of $\mathrm{OH}$ concentrations in the atmosphere have established that the annual globally weighted average $\mathrm{OH}$ concentration in the troposphere is roughly $10^{6} \mathrm{~cm}^{-3}$ (Prinn et al., 2001; Krol et al., 2003). During the mean aerosol lifetime of about one week, the atmospheric aerosol and methane $\mathrm{OH}$ exposure is about $168 \cdot 10^{6} \mathrm{~cm}^{-3} \mathrm{~h}$. Within the 6 hour aerosol lifetime (used for the yield calculations) in our smog chamber the $\mathrm{OH}$ exposure is roughly five times lower. The amount of methane reacted during an aerosol life time is still few times higher in the smog chamber than in the atmosphere. Therefore we had to scale the methane yield by the amount of methane reacted. For all these reasons it is presumable that the atmospheric relevance of our findings might be even lower. Additionally, the methane carbon contribution of $0.13 \%$ to global SOA mass should be considered an upper limit, especially since it was determined at SOA mass concentrations which are clearly above the atmospherically relevant levels.

\subsection{HCHO experiments}

Possible methane oxidation products that could be responsible for our findings are mainly methyl hydroperoxide and formaldehyde. An MCMv3.1 model run for the 'intermediate $\mathrm{NO}_{\mathrm{x}}$ experiments' with $80 \mathrm{ppbv} \alpha$-pinene reveals that the photo stationary steady state mixing ratio of formaldehyde from methane oxidation is between 30 and 40 ppbv. In the 'no- $\mathrm{NO}_{\mathrm{x}}$ ' experiments this is even lower. In 
experimental series 4 we performed an $\alpha$-pinene ozonolysis experiment in the presence of $40 \mathrm{ppbv} \mathrm{H}^{13} \mathrm{CHO}$ with the lights off. We found that the $\chi^{\mathrm{E}}\left({ }^{13} \mathrm{C}\right)$ in the aerosol was more than an order of magnitude lower than that produced by $\alpha$-pinene ozonolysis in an aged gas phase containing methane reaction products (series 1 and 2). Not even an $\alpha$-pinene ozonolysis experiment in the chamber containing over $800 \mathrm{ppbv} \mathrm{H}^{13} \mathrm{CHO}$ as the only labeled precursor could reach the $\chi^{\mathrm{E}}\left({ }^{13} \mathrm{C}\right)$ measured during such an $\alpha$-pinene ozonolysis. This suggests that HCHO is only involved in methane SOA formation to a very minor extent. Interestingly the $\chi^{\mathrm{E}}\left({ }^{13} \mathrm{C}\right)$ can be substantially (by up to a factor of 3 ) increased in the $40 \mathrm{ppbv} \mathrm{H}^{13} \mathrm{CHO}$ experiment by turning the lights on, indicating a light induced heterogeneous uptake. However this increase is still too low to explain the $\chi^{\mathrm{E}}\left({ }^{13} \mathrm{C}\right)$ obtained in the aerosol from the methane experiments. These findings are consistent with the result of Kroll et al. (2005) who studied the reactive uptake of simple carbonyl species onto inorganic aerosol and did not observe any growth for formaldehyde at 5 ppmv. We also tested the formaldehyde uptake into the inorganic seed aerosol. Even though we sampled for more than twice as long as during the ${ }^{13} \mathrm{CH}_{4}$ experiments from a chamber containing only the inorganic seed (ammonium bisulfate) and $\mathrm{H}^{13} \mathrm{CHO}$ at $\mathrm{RH}=$ $85 \%$, we did not obtain enough carbon mass on the filters and tinfoils to detect formaldehyde.

\section{Summary and conclusions}

By using ${ }^{13} \mathrm{C}$ labeled methane, a stable isotope of carbon atoms, we show that its oxidation products are taken up by pre-existing organic seed aerosols $(1,3,5, \mathrm{TMB}$ or 
$\alpha$-pinene). The atmospheric relevance of these findings are likely small and the global methane contribution to SOA is an estimated maximum of $0.105 \mathrm{TgC}_{\mathrm{gear}}{ }^{-1}$ or about $0.13 \%$ of the atmospheric aerosol carbon mass. However, the mechanism by which $\mathrm{CH}_{4}$ oxidation products partition to the particle phase remains only partially elucidated. We show that formaldehyde, an important photo-oxidation product of $\mathrm{CH}_{4}$, is by no means sufficient to explain the observed $\mathrm{CH}_{4}$ SOA yields. The effect of organic aerosol composition on the methane yield is unknown and merits further study. For the first time we have shown in laboratory experiments that oxidation products of a fairly inert and very volatile precursors can be found in the condensed phase. Based on these findings, we conclude that there is strong evidence that every existing VOC must be able to contribute, at least to some extent, to the global burden of particulate matter.

\section{Acknowledgements}

This work was supported by the Swiss National Science Foundation (200020_135307 and 20020_152907) and the EU 7th Framework project EUROCHAMP-2. Peter F. DeCarlo is grateful for US NSF postdoctoral support.

\section{References}

Barmet, P., Dommen, J., DeCarlo, P. F., Tritscher, T., Praplan, A. P., Platt, S. M., Prévôt, A. S. H., Donahue, N. M., and Baltensperger, U.: OH clock determination by proton transfer reaction mass spectrometry at an environmental chamber, Atmos. Meas. Tech., 5, 647-656, doi:10.5194/amt-5-647-2012, 2012.

Cantrell, C. A., Shetter, R. E., Mcdaniel, A. H., Calvert, J. G., Davidson, J. A., Lowe, D. C., Tyler, S. C., Cicerone, R. J., and Greenberg, J. P.: Carbon kinetic isotope effect in the oxidation of methane by the hydroxyl radical, J. Geophys. Res., 95, 22 455-22,462, doi:10.1029/JD095iD13p22455, 1990.

Czoschke, N. M., Jang, M., and Kamens, R. M.: Effect of acidic seed on biogenic secondary organic aerosol growth, Atmos. Environ., 37, 4287-4299, doi: 10.1016/S1352-2310(03)00511-9, 2003. 
Dlugokencky, E. J., Bruhwiler, L., White, J. W. C., Emmons, L. K., Novelli, P. C., Montzka, S. A., Masarie, K. A., Lang, P. M., Crotwell, A. M., Miller, J. B., and Gatti, L. V.: Observational constraints on recent increases in the atmospheric $\mathrm{CH}_{4}$ burden, Geophys. Res. Lett., 36, doi:10.1029/2009GL039780, 2009.

Dommen, J., Hellen, H., Saurer, M., Jaeggi, M., Siegwolf, R., Metzger, A., Duplissy, J., Fierz, M., and Baltensperger, U.: Determination of the aerosol yield of isoprene in the presence of an organic seed with carbon isotope analysis, Environ. Sci. Technol., 43, 6697-6702, doi:10.1021/es9006959, 2009.

Gao, S., Keywood, M., Ng, N. L., Surratt, J., Varutbangkul, V., Bahreini, R., Flagan, R. C., and Seinfeld, J. H.: Low-molecular-weight and oligomeric components in secondary organic aerosol from the ozonolysis of cycloalkenes and a-pinene, J. Phys. Chem. A, 108, 10 147-10 164, doi:10.1021/jp047466e, 2004a.

Gao, S., Ng, N. L., Keywood, M., Varutbangkul, V., Bahreini, R., Nenes, A., He, J. W., Yoo, K. Y., Beauchamp, J. L., Hodyss, R. P., Flagan, R. C., and Seinfeld, J. H.: Particle phase acidity and oligomer formation in secondary organic aerosol, Environ. Sci. Technol., 38, 6582-6589, doi:10.1021/es049125k, 2004b.

Hallquist, M., Wenger, J. C., Baltensperger, U., Rudich, Y., Simpson, D., Claeys, M., Dommen, J., Donahue, N. M., George, C., Goldstein, A. H., Hamilton, J. F., Herrmann, H., Hoffmann, T., Iinuma, Y., Jang, M., Jenkin, M. E., Jimenez, J. L., Kiendler-Scharr, A., Maenhaut, W., McFiggans, G., Mentel, T. F., Monod, A., Prévôt, A. S. H., Seinfeld, J. H., Surratt, J. D., Szmigielski, R., and Wildt, J.: The formation, properties and impact of secondary organic aerosol: current and emerging issues, Atmos. Chem. Phys., 9, 5155-5236, 2009.

Hildebrandt, L., Henry, K. M., Kroll, J. H., Worsnop, D. R., Pandis, S. N., and Donahue, N. M.: Evaluating the mixing of organic aerosol components using high-resolution aerosol mass spectrometry, Environ. Sci. Technol., 45, 6329-6335, doi:10.1021/es200825g, 2011.

Iinuma, Y., Boge, O., Gnauk, T., and Herrmann, H.: Aerosol-chamber study of the $\alpha$-pinene $/ \mathrm{O}_{3}$ reaction: influence of particle acidity on aerosol yields and products, Atmos. Environ., 38, 761-773, doi:10.1016/j.atmosenv.2003.10.015, 2004.

IPCC: Climate Change 2013: The Physical Science Basis. Contribution of Working Group I to the Fifth Assessment Report of the Intergovernmental Panel on Climate Change, Cambridge University Press, 2014.

Jang, M. S., Czoschke, N. M., Lee, S., and Kamens, R. M.: Heterogeneous atmospheric aerosol production by acid-catalyzed particle-phase reactions, Science, 298, 814-817, doi:10.1126/science.1075798, 2002.

Jenkin, M. E. and Hayman, G. D.: Photochemical ozone creation potentials for oxygenated volatile organic compounds: sensitivity to variations in kinetic and mechanistic parameters, Atmos. Environ., 33, 1275-1293, 1999. 
Junkermann, W. and Burger, J.: A new portable instrument for continuous measurement of formaldehyde in ambient air, J. Atmos. Ocean. Tech., 23, 38-45, doi:10.1175/JTECH1831.1, 2006.

Krol, M. and Lelieveld, J.: Can the variability in tropospheric $\mathrm{OH}$ be deduced from measurements of 1,1,1-trichloroethane (methyl chloroform)?, J. Geophys. Res. Atmos., 108, D3, doi:10.1029/2002JD002423, 2003.

Kroll, J. H., Ng, N. L., Murphy, S. M., Varutbangkul, V., Flagan, R. C., and Seinfeld, J. H.: Chamber studies of secondary organic aerosol growth by reactive uptake of simple carbonyl compounds, J. Geophys. Res., 110, D23 207, doi: 10.1029/2005JD006004, 2005.

Lindinger, W., Hansel, A., and Jordan, A.: Online monitoring of volatile organic compounds at pptv levels by means of proton-transfer-reaction mass spectrometry (PTR-MS) medical applications, food control and environmental research, Int. J. Mass Spectrom., 173, 191-241, 1998.

Matsunaga, A. and Ziemann, P. J.: Gas-wall partitioning of organic compounds in a teflon film chamber and potential effects on reaction product and aerosol yield measurements, Aerosol Sci. Technol., 44, 881-892, doi: 10.1080/02786826.2010.501044, 2010.

Metzger, A., Dommen, J., Gaeggeler, K., Duplissy, J., Prévôt, A. S. H., Kleffmann, J., Elshorbany, Y., Wisthaler, A., and Baltensperger, U.: Evaluation of 1,3,5 trimethylbenzene degradation in the detailed tropospheric chemistry mechanism, MCMv3.1, using environmental chamber data, Atmos. Chem. Phys., 8, 6453-6468, doi:10.5194/acp-8-6453-2008, 2008.

Paulsen, D., Dommen, J., Kalberer, M., Prévôt, A. S. H., Richter, R., Sax, M., Steinbacher, M., Weingartner, E., and Baltensperger, U.: Secondary organic aerosol formation by irradiation of 1,3,5-trimethylbenzene- $\mathrm{NO}_{\mathrm{x}}-\mathrm{H}_{2} \mathrm{O}$ in a new reaction chamber for atmospheric chemistry and physics, Environ. Sci. Technol., 39, 2668-2678, doi:10.1021/es0489137, 2005.

Prinn, R. G.: Evidence for substantial variations of atmospheric hydroxyl radicals in the past two decades, Science, 293, 1048-1048, 2001.

Saunders, S. M., Jenkin, M. E., Derwent, R. G., and Pilling, M. J.: Protocol for the development of the Master Chemical Mechanism, MCMv3 (Part A): tropospheric degradation of non-aromatic volatile organic compounds, Atmos. Chem. Phys., 3, 161-180, 2003.

Spahni, R., Chappellaz, J., Stocker, T. F., Loulergue, L., Hausammann, G., Kawamura, K., Fluckiger, J., Schwander, J., Raynaud, D., Masson-Delmotte, V., and Jouzel, J.: Atmospheric methane and nitrous oxide of the late Pleistocene from Antarctic ice cores, Science, 310, 1317-1321, doi:10.1126/science.1120132, 2005. 
Taira, M. and Kanda, Y.: Continuous generation system for low-concentration gaseous nitrous-acid, Anal. Chem., 62, 630-633, 1990.

Volkamer, R., Ziemann, P. J., and Molina, M. J.: Secondary Organic Aerosol Formation from Acetylene $\left(\mathrm{C}_{2} \mathrm{H}_{2}\right)$ : seed effect on SOA yields due to organic photochemistry in the aerosol aqueous phase, Atmos. Chem. Phys., 9, 1907-1928, 2009.

Williams, B. J., Goldstein, A. H., Kreisberg, N. M., and Hering, S. V.: An in-situ instrument for speciated organic composition of atmospheric aerosols: Thermal Desorption Aerosol GC/MS-FID (TAG), Aerosol Sci. Technol., 40, 627-638, doi:10.1080/02786820600754631, 2006.

Zhang, X., Cappa, C. D., Jathar, S. H., McVay, R. C., Ensberg, J. J., Kleeman, M. J., and Seinfeld, J. H.: Influence of vapor wall loss in laboratory chambers on yields of secondary organic aerosol, Proc. Natl. Acad. Sci. USA, 111, 5802-5807, doi:10.1073/pnas.1404727111, 2014. 
Table 1: Overview of the experimental series performed to determine the carbon yield of methane. The last column indicates whether HONO or NO was added or not.

\begin{tabular}{|c|c|c|c|c|c|c|}
\hline $\begin{array}{c}\text { Experimental } \\
\text { series }\end{array}$ & Date & Duration & $\begin{array}{c}\text { Inorgranic } \\
\text { seed aerosol }\end{array}$ & $\begin{array}{l}\text { Organic } \\
\text { precursor }\end{array}$ & NO/HONO & $\begin{array}{c}\text { Formaldehyde } \\
(\mathbf{p p b})\end{array}$ \\
\hline Series 1 & 11.2010 & 3 days & $\left(\mathrm{NH}_{4}\right)_{2} \mathrm{SO}_{4}$ & $\alpha$-pinene & $\mathrm{NO}$ & - \\
\hline Series 2 & 04.2012 & 4 days & $\mathrm{NH}_{4} \mathrm{HSO}_{4}$ & $\alpha$-pinene & - & - \\
\hline Series 3 & 05.2012 & 2 days & $\mathrm{NH}_{4} \mathrm{HSO}_{4}$ & 1,3,5-TMB & HONO & - \\
\hline Series 4 & 04.2012 & $2 \times 1$ day & $\mathrm{NH}_{4} \mathrm{HSO}_{4}$ & $\alpha$-pinene & - & 40 and 800 \\
\hline
\end{tabular}


Table 2: Aerosol carbon yields of methane under different conditions and by varying organic and inorganic precursor seeds.

\begin{tabular}{|c|c|c|}
\hline $\begin{array}{l}\text { sample } \\
\text { substrate (hours after lights on) }\end{array}$ & $\begin{array}{c}\text { mean }{ }^{13} \mathrm{CH}_{4} \text { reacted } \\
{[\mathrm{ppbv}]\left({ }_{-}^{+} \mathrm{std} . \mathrm{dev} \cdot[\mathrm{ppbv}]\right)}\end{array}$ & $\begin{array}{c}\text { wall-loss-corrected yields } \\
{[\%]\left({ }_{-}^{+} \text {uncertainty [\%]) }\right.}\end{array}$ \\
\hline \multicolumn{3}{|c|}{$\alpha-$ pinene with intermediate $\mathrm{NO}_{\mathrm{x}}$} \\
\hline tinfoil $(5 \mathrm{~h})$ & $38\left({ }_{-18}^{+37}\right)$ & $0.09\left({ }_{-0.06}^{+0.14}\right)$ \\
\hline \multicolumn{3}{|c|}{$\alpha$-pinene without $\mathrm{NO}_{\mathrm{x}}$} \\
\hline tinfoil $(0 \mathrm{~h})$ & 0 & \\
\hline filter $(0 \mathrm{~h})$ & 0 & \\
\hline tinfoil (4h) & $33\left(\begin{array}{c}+11 \\
-9\end{array}\right)$ & $0.07\left({ }_{-0.03}^{+0.06}\right)$ \\
\hline filter $(4 \mathrm{~h})$ & $33\left(\begin{array}{c}+11 \\
-9\end{array}\right)$ & $0.06\left({ }_{-0.03}^{+0.07}\right)$ \\
\hline filter $(6 \mathrm{~h})$ & $42\left({ }_{-11}^{+14}\right)$ & $0.09\left({ }_{-0.04}^{+0.11}\right)$ \\
\hline \multicolumn{3}{|c|}{ TMB with $\mathrm{HONO}$} \\
\hline tinfoil $(10 \mathrm{~h})$ & $30\left(\begin{array}{c}+10 \\
-8\end{array}\right)$ & $0.007\left({ }_{-0.0020}^{+0.0036}\right)$ \\
\hline filter $(10 \mathrm{~h})$ & $30\left(\begin{array}{c}+10 \\
-8\end{array}\right)$ & $0.009\left({ }_{-0.0028}^{+0.0051}\right)$ \\
\hline filter $(18 \mathrm{~h})$ & $54\left({ }_{-15}^{+18}\right)$ & $0.017\left({ }_{-0.0063}^{+0.0139}\right)$ \\
\hline filter $(22 \mathrm{~h})$ & $80\left({ }_{-22}^{+26}\right)$ & $0.021\left({ }_{-0.0089}^{+0.0211}\right)$ \\
\hline
\end{tabular}




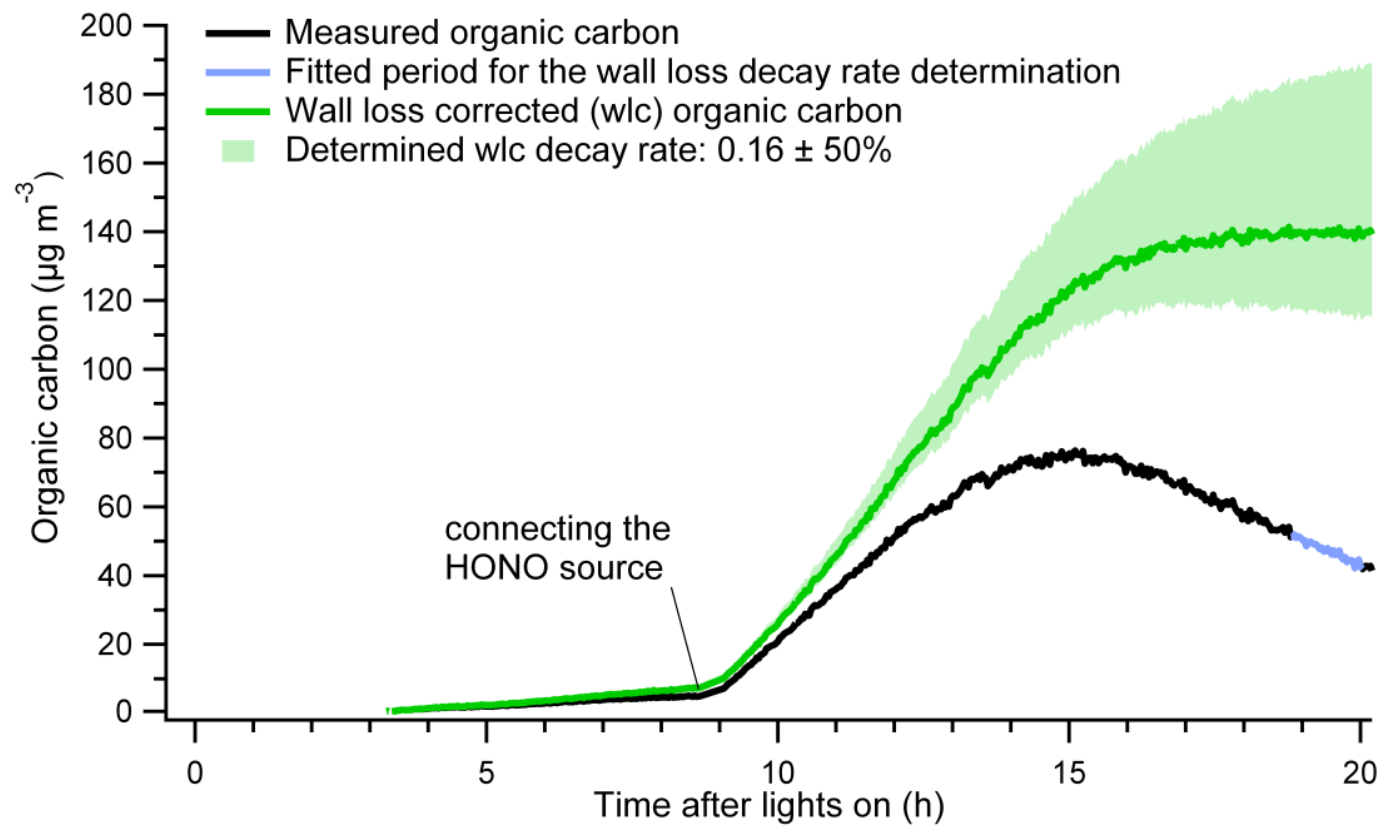

Figure 1: Example of a wall loss correction (here of series 3): the solid black line shows the organic carbon mass measured by an aerosol mass spectrometer (AMS). The wall loss rate $(\mathrm{kw})$ was estimated semi-empirically by fitting the observed decay in mass due to wall loss (during the period marked in blue). The solid green line is the wall loss corrected SOA carbon mass. The bright green background indicates an uncertainty estimated by varying $\mathrm{k}_{\mathrm{w}}$ by $\pm 50 \%$. 


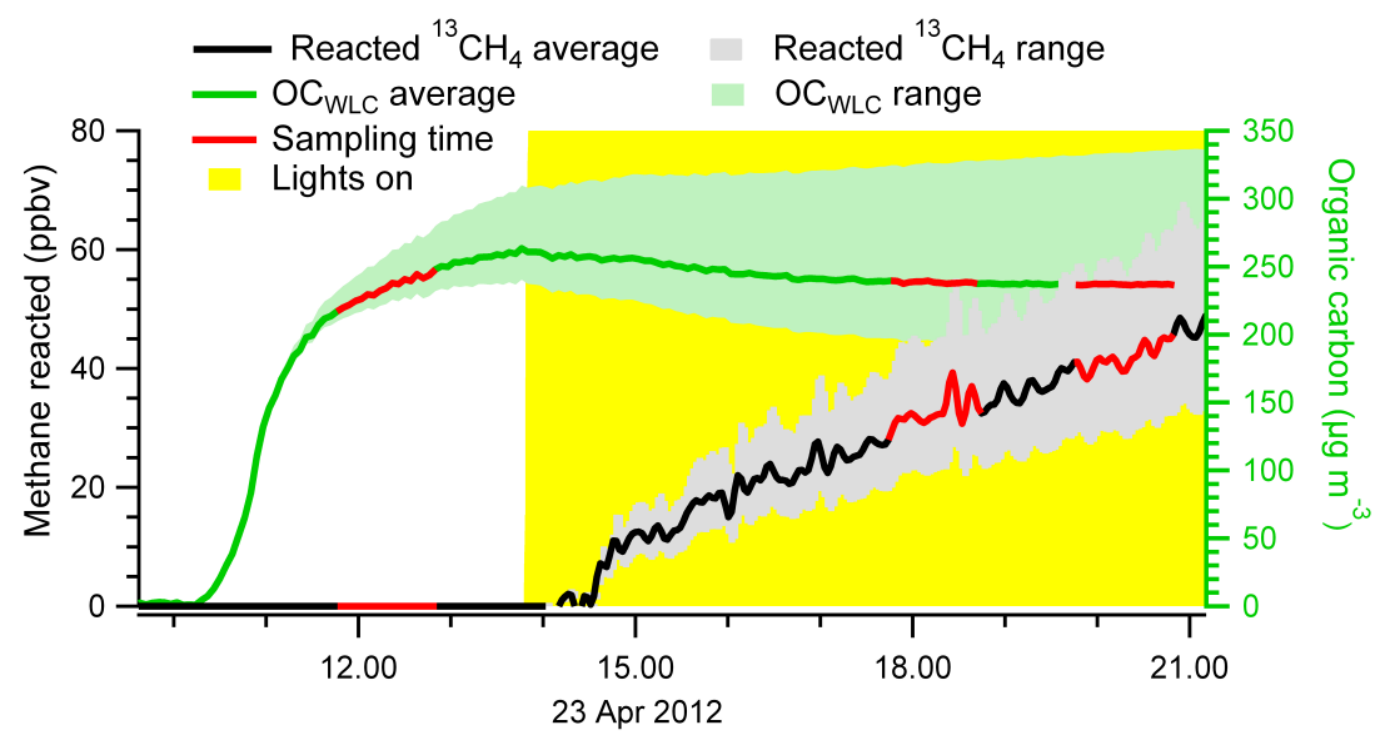

Figure 2: Example of a typical experimental procedure: the initial stage of series 2 starts with the ozonolysis of $\alpha$-pinene and the formation of SOA (white background). The green line shows the total organic carbon mass of the aerosols. After all of the $\alpha$-pinene had reacted, $75 \mathrm{ppmv}$ of ${ }^{13} \mathrm{CH}_{4}$ was added (not shown here), and a longer period of photochemical oxidation by $\mathrm{OH}$ with the smog chamber lights switched on followed (yellow background). The methane reacted (gray line) is based on the $\mathrm{OH}$ concentration determined by the decay of an $\mathrm{OH}$-tracer (in this case: butanol-d9). The periods where filter and tinfoil samples were taken are marked in red. 


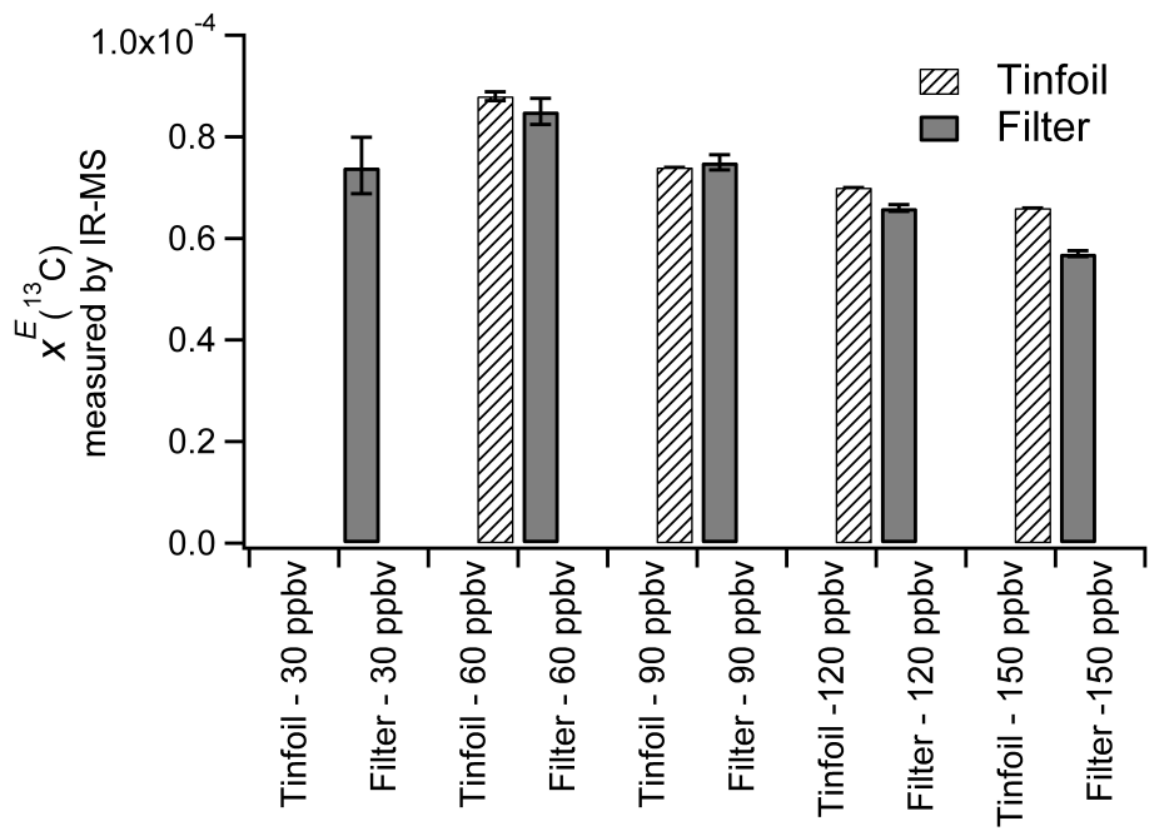

Figure 3: Excess atom fraction of ${ }^{13} \mathrm{C}\left(\chi^{\mathrm{E}}\left({ }^{13} \mathrm{C}\right)\right)$ measured by IR-MS. $\chi^{\mathrm{E}}\left({ }^{13} \mathrm{C}\right)$ generally decreases with increasing SOA mass concentration, which is formed by the stepwise addition of $\alpha$-pinene (from 30 to $150 \mathrm{ppbv}$ ). 


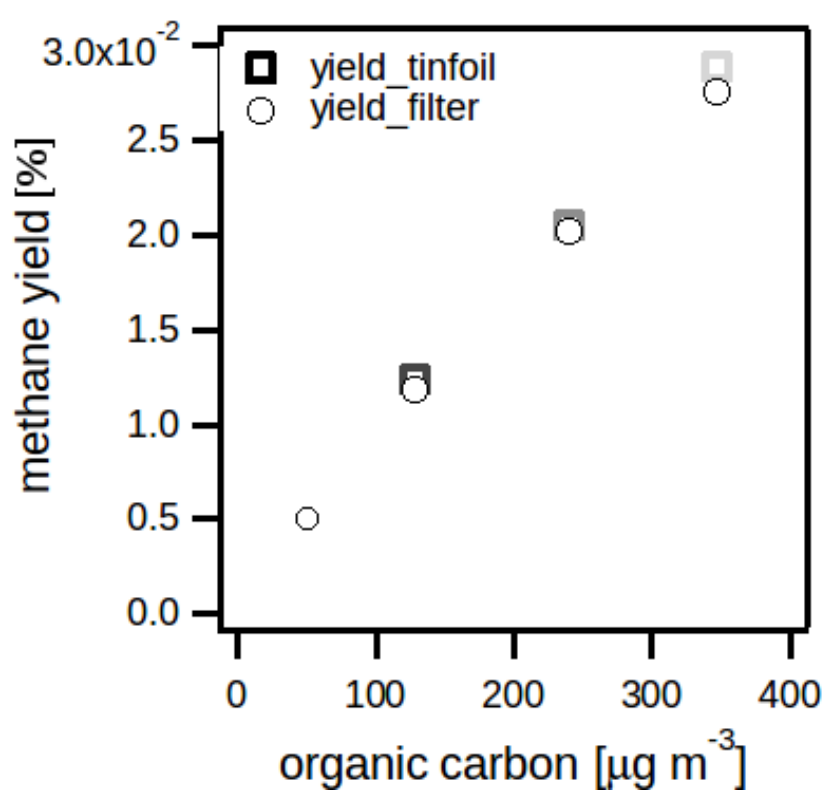

Figure 4: Wall loss corrected carbon yield of methane at different SOA concentration. For this experiment $\alpha$-pinene was added stepwise into the smog chamber (day 3 of series 2). The chamber contained 500 ppbv of ozone, a mixture of $\alpha$-pinene oxidation products, an inorganic seed as well as more than $170 \mathrm{ppbv}$ methane reacted (in total). Lights were off during the whole period. 